\title{
DECENTRALISED GREEN POWER GENERATION USING METHYL ESTERS OF NON- EDIBLE OILS
}

\author{
S. Durairaj, K. Sathiyasekar, M. Ilangkumaran
}

Original scientific paper

Research work on renewable energy systems for rural electrification have been quite intensive in recent years. In remote areas, some villages are still not reach of electricity because providing grid connection is impossible. Approximately twenty percent of global population are living without electricity in the world. For enhancement of rural livelihood, use of green energy sources encompasses greater employment opportunity, energy security and minimizes the greenhouse effects. The conventional method of local generation uses diesel generator that is not environment friendly. Bio-fuels have been the optimistic choice to meet this requirement. Biodiesel is a renewable source which has nearly the same efficiency as conventional petro-diesel. This paper experimentally investigates biodiesel blends (Diesel+Biodiesel) derived from non-edible oils as an alternative energy source for operating the diesel power generator. In this study, seven methyl esters extracted from non-edible oils of pongamia, jatroba, mahua, mesuaferra, linseed, neem and cotton seed are considered. The generator performances such as voltage regulation, frequency, fuel consumption, efficiency and emission characteristics are found in various load conditions. Based on the observations, pongamia oil was found to be a good alternative fuel for power generation.

Keywords: bio-diesel; distributed generation; efficiency; emission; frequency; fuel consumption; green energy; voltage regulation

Decentralizirana proizvodnja zelene energije pomoću metil estera nejestivih ulja

Izvorni znanstveni rad Istraživački radovi o sustavima obnovljivih izvora energije za elektrifikaciju sela vrlo su intenzivni posljednjih godina. U udaljenim područjima neka su sela još uvijek izvan dosega električne energije jer je nemoguće povezivanje mrežnog sustava. U svijetu oko dvadeset posto svjetske populacije živi bez struje. Za poboljšanje ruralnog življenja, uporaba zelenih izvora energije obuhvaća veću mogućnost zapošljavanja, energetsku sigurnost i smanjenje učinaka staklenika. Konvencionalna metoda lokalne proizvodnje koristi dizel generator koji nije prihvatljiv za okoliš. Biogoriva su optimistični izbor za ispunjavanje ovog zahtjeva. Biodizel je obnovljivi izvor koji ima gotovo jednaku učinkovitost kao i konvencionalni petrodizel. Ovaj rad pokusno istražuje mješavine biodizela (dizel + biodizel) dobivene od nejestivih ulja kao alternativni izvor energije za pogon dizelskog generatora. U ovoj studiji se uzima u obzir sedam metilnih estera ekstrahiranih iz nejestivih ulja pongamije (indijske breze), jatrobe (jatrophe), mahuae, mesua ferrae (nageškara), sjemenki lana, neema (nim drveta) i sjemenki pamuka. Performanse generatora kao što su regulacija napona, frekvencija, potrošnja goriva, učinkovitost i emisijske značajke nalaze se u različitim uvjetima opterećenja. Na temelju opažanja, nađeno je da je ulje pongamije dobro alternativno gorivo za proizvodnju električne energije.

Ključne riječi: biodizel; distribuirana proizvodnja; učinkovitost; emisija; frekvencija; potrošnja goriva; zelena energija; regulacija napona

\section{Introduction}

In nearly all developing countries, the increasing population growth and industrialization have resulted in the slow expansion of electrical distribution networks and formation of regions with high load density creating reliability problems such as diminished power quality and voltage instability [1]. At the same time, the non-urban areas suffer from the problems, such as voltage sag and high losses across distribution lines. Distributed generation based on green power sources is considered as a suitable option to address the aforementioned electrical network problems. In addition, the influence of environmental aspects must be considered when green power sources are employed [2]. To provide the electricity for remote locations, off grid distributed generating system is the best alternative [3]. Most of the unelectrified villages are rich in the availability of renewable energy resources like solar, small hydro, biomass etc. Utilization of these resources has the potential to meet demand of rural areas including cooking, lighting, heating and cooling and employment. Energy access in rural areas can help in improving agricultural condition, per capita income and poverty level.

In remote locations, diesel generators are used to provide the power supply. In such locations, the feed stocks of non-edible oil crops are widely available. In the past decade researches were made on the use of plants oils and fats as a sustainable energy source [4]. Biodiesel is eco-friendly and can be synthesized from both edible and non-edible oils [5]. For biodiesel production non edible oil is the reliable feed stock [6, 7]. More than 350 oil crops were identified as potential sources for biodiesel production and can be used for different applications [8]. Use of biodiesel as a source for electric power generation is gradually increased in the past few decades. Voltage regulation and frequency of biodiesel derived ground nut oil is similar to diesel [9]. Mervecetinkaya et al. have identified improvement in performance and emission characteristics when using the waste cooking oil for power generation $[10,11]$. Biodiesels of cotton seed and palm oil give better electrical efficiency $[12,13]$. The overall efficiency of Jatropha and Karanj biodiesel was enhanced by blending of diesel [14]. The fuel consumption of soya bean biodiesel is less when compared to castor oil biodiesel [15]. Emissions such as $\mathrm{CO}, \mathrm{SO}_{2}, \mathrm{C}_{x} \mathrm{H}_{y}$ were reduced in blends of soybean biodiesel [16]. PM, elemental/organic carbon, and $\mathrm{PAH}$ were reduced using waste-edible-oil biodiesel [17]. J. M. Kennedy applied rapeseed methyl ester as a fuel for an electric generator and observed the emission characteristics [18]. The rest of this paper is organized as follows: Experimental procedure for preparation of biodiesel from the resource seeds and experimental testing procedures are summarized in Section 2. The comparative analyses of the results are explained in 
Section 3. Finally, in Section 4, the paper concludes with suggestions for future research.

\section{Material and methods}

\subsection{Test fuel}

From the seeds or kernels of Pongamia, Jatropha, Cotton, Neem, linseed, Mahua, and Meusa Ferra the nonedible oils are extracted. Extraction of oil from seeds can be done by a screw press; it can extract $68-80 \%$ of the oil from seeds [19]. The extracted oil needs further treatment of filterization and degumming for removal of dirt and other inert materials. By transestrification process, the problems associated with crude oils such as high viscosity, low volatility and polyunsaturation are overcome. Transesterification is considered as one of the best methods among various approaches due to its low cost and simplicity. Using this method high purity and better yield of biodiesel was achieved in a short time [20]. The extracted oil is heated to a temperature of $60{ }^{\circ} \mathrm{C}$. Then for every 1 litre of oil, the mixture of $150 \mathrm{ml}$ of methanol and $7 \mathrm{gm}$ of $\mathrm{NaOH}$ was added to heated oil and stirred for 90 minutes at a speed of $750 \mathrm{rpm}$. Then the content is kept for about 30 minutes without interruption. Now the glycerol occupies the bottom layer and the biodiesel forms the top layer. Then the biodiesel is moved to washing compartment. Washing of biodiesel is categorized by 4 washes using water at the temperature of $50{ }^{\circ} \mathrm{C}$. Firstly with $150 \mathrm{ml}$ of acetic acid and then with 75 $\mathrm{ml}$ of acetic acid and the next two washes are with hot water alone. To remove the moisture content, the washed fuel is heated up to $110{ }^{\circ} \mathrm{C}$. Finally the extracted bio diesel is filtered with 5 micron filter. The above process takes 8 hours.

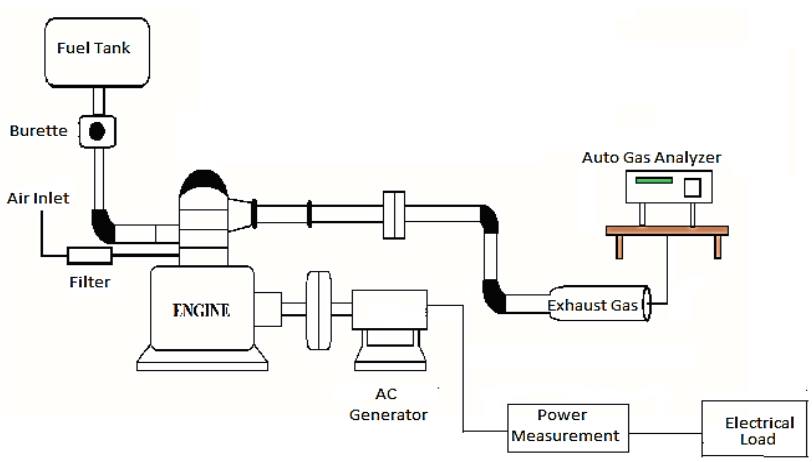

Figure 1 Schematic arrangement of an experimental setup

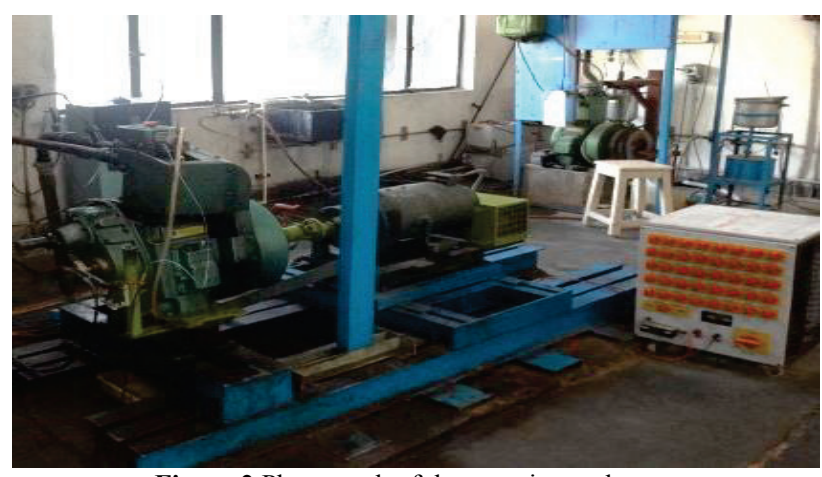

Figure 2 Photograph of the experimental setup

\subsection{Performance testing on generator}

The schematic arrangement and photograph of an experimental setup is shown in Figs. 1 and 2; the specifications of the engine and the alternator are given in Tabs. 1 and 2.

Table 1 Engine Specifications

\begin{tabular}{|l|l|}
\hline \multicolumn{1}{|c|}{ Parameters } & \multicolumn{1}{c|}{ Specification / Rating } \\
\hline Make & Kirloskar \\
\hline Power & $4.7 \mathrm{~kW}$ \\
\hline Number of Cylinder & 1 \\
\hline Type & 4 stroke, Direct Injection, Air cooled \\
\hline
\end{tabular}

Table 2 Alternator Specifications

\begin{tabular}{|l|l|}
\hline \multicolumn{1}{|c|}{ Parameters } & \multicolumn{1}{c|}{ Rating } \\
\hline KVA rating & 5 \\
\hline No. of Phases & 1 \\
\hline Frequency & $50 \mathrm{~Hz}$ \\
\hline Speed & $1500 \mathrm{rpm}$ \\
\hline Voltage rating & $240 \mathrm{~V}$ \\
\hline
\end{tabular}

The prepared biodiesel is used as a fuel to run the diesel power generator. The alternator was loaded with a resistive and non-linear load. The experimental setup was arranged to measure fuel consumption, load voltage, current, frequency and emission parameters of each fuel. The test was conducted for the blend of B50 (50\% biodiesel and 50\% Petro-diesel). To get proper data from the experiment, some salient points should be considered before taking the measurements. The engine was originally designed to operate on diesel fuel. To measure the baseline data, the engine was operating with diesel fuel at different load conditions for 30 minutes. Similarly the test was performed for biodiesels. During the tests, the engine starts with a warm up period of 20 min to attain steady state conditions and minimize the residuals from previous fuel. From the measured data, total fuel consumption, efficiency and voltage regulations $(V R)$ are calculated as follows:

The voltage regulation $(V R)$ is calculated by Eq. (1):

$V R(\%)=\frac{V_{0}-V}{V} \times 100$

Overall efficiency $(\eta)$ is calculated by Eq. (2):

$\eta(\%)=\frac{E_{\text {out }}}{E_{\text {in }}} \times 100$

Energy output $\left(E_{\text {out }}\right)$ is calculated by Eq. (3):

$E_{\text {out }}(\mathrm{kW})=\frac{V \times I}{1000}$

Energy input $\left(E_{\text {in }}\right)$ is calculated by Eq. (4):

$E_{\text {in }}(\mathrm{kW})=\frac{T F C}{C V}$

where: $T F C$ - Total fuel consumption $(\mathrm{kg} / \mathrm{s}), C V-$ Calorific value of fuel $(\mathrm{kJ} / \mathrm{kg})$. 
Total fuel consumption (TFC) is calculated by Eq. (5):

$\operatorname{TFC}(\mathrm{kg} / \mathrm{s})=\frac{q}{t} \times \rho$,

where: $q$ - Volume of fuel consumed $\left(50 \times 10^{-6} \mathrm{~m}^{3}\right), t-$ time taken for $50 \mathrm{~cm}^{3}$ of fuel consumption in $\mathrm{s}, \rho-$ density of the fuel $\left(\mathrm{kg} / \mathrm{m}^{3}\right)$.

\section{Results and discussion \\ 3.1 Overall efficiency}

Fig. 3 shows the efficiency of various biodiesels for different value of resistive load conditions. The overall efficiency of petro diesel is higher for all load conditions when compared to biodiesels, whereas pongamia has higher efficiency among the biodiesels. At full load condition the efficiency of pongamia biodiesel is found to be $37.15 \%$ and petro diesel is $38.56 \%$, hence the engine was derated by only $1.4 \%$. In non-linear load, due to voltage drop caused by inductive reactance, the output power is reduced. Hence the efficiency is slightly reduced which will not create much impact on the performance as compared to resistive load. The efficiency depends upon the combustion quality of the fuel. Methyl ester blends give less combustion quality than that of diesel.

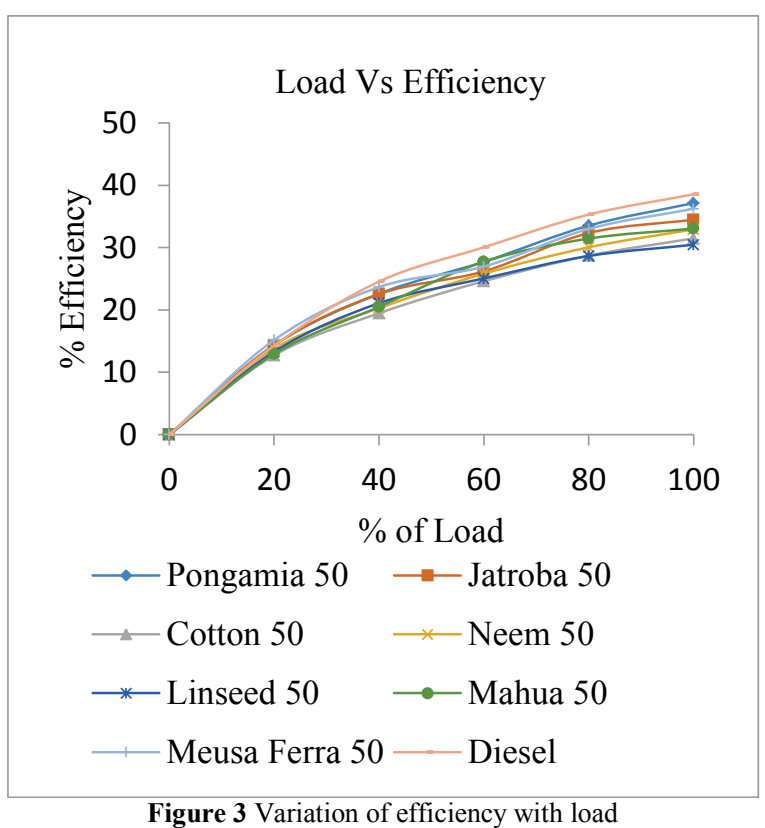

\subsection{Load frequency}

The variation in frequency for different biodiesels is presented in Fig. 4. It shows that the frequency decreased with an increase in load, because the engine is operated in an open loop system (ie engine speed is not adjusted). The variation in frequency is similar to that of diesel. At full load condition linseed and cotton seed oils have significant deviations compared to other biodiesels. Among the biodiesels pongamia has least variation of $0.13 \mathrm{~Hz}$. This reduction in frequency can be overcome by increasing the speed of the engine.

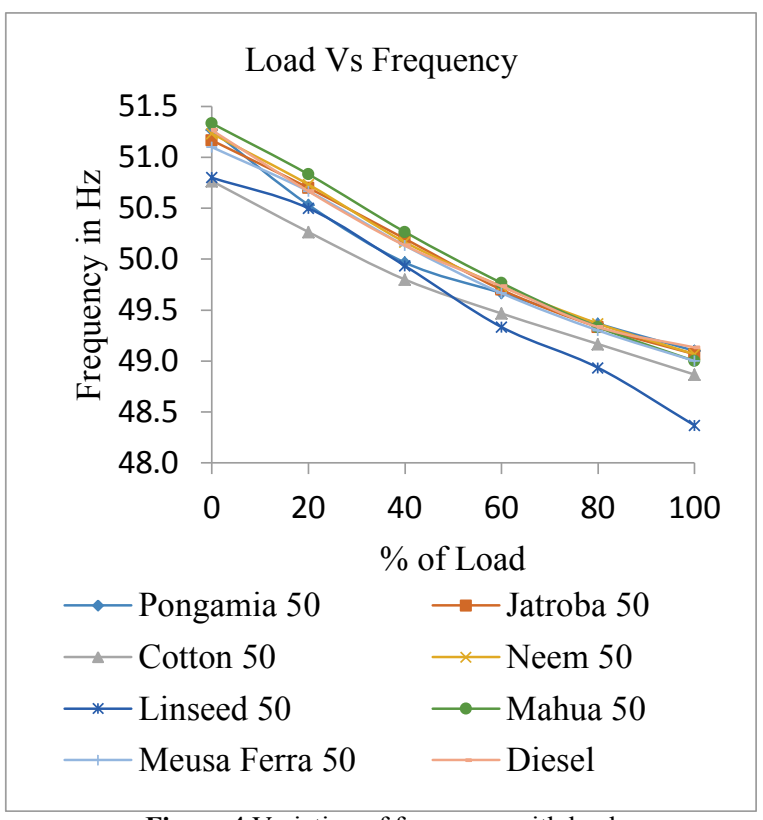

Figure 4 Variation of frequency with load

\subsection{Voltage regulation}

Fig. 5 shows the voltage regulation for different biodiesels for resistive load. With constant excitation, the output voltage is reduced with increase in load due to decrease in engine speed. From the results metyl ester blends of linseed, mahua, mesua ferra have variation above $10 \%$. The remaining fuels have acceptable variation range of below $10 \%$. If excitation is adjusted, it results in better voltage regulation.

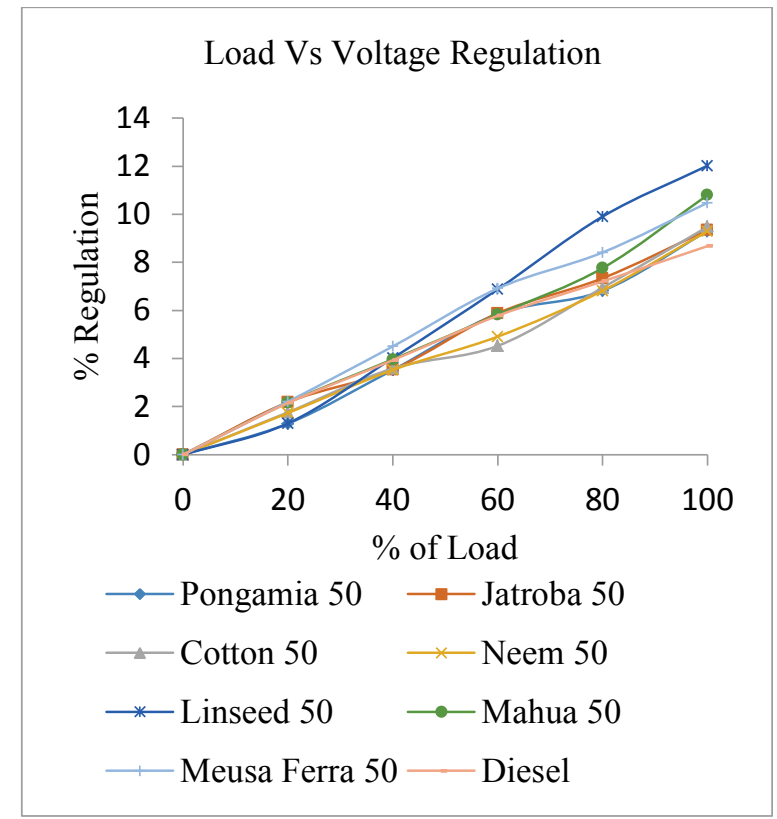

Figure 5 Variation voltage regulation for R load

The voltage regulation for non-linear load is shown in Fig. 6. From the results the voltage drop across the load is reduced as compared to resistive load. As a result, the voltage regulation was improved by around $4 \%$. So all fuels have the acceptable level of regulation. 


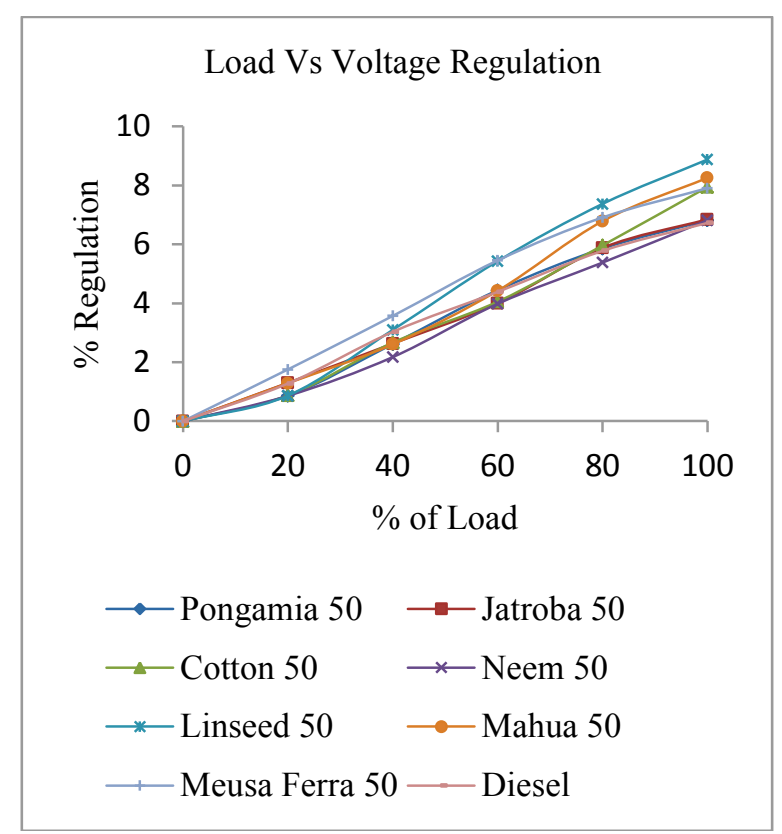

Figure 6 Variation of voltage regulation for non-linear load

\subsection{Fuel consumption}

The fuel consumption of various fuels is shown in Fig. 7. Invariably the fuel consumption in all fuels including diesel increases from minimum to maximum load. From the results, the pongamia has the least fuel consumption among the biodiesels for all load conditions. At full load condition, $0.5 \%$ of fuel was consumed additionally compared to diesel. Fuel consumption depends on the mass flow rate of Hydrogen in the fuel. Hydrogen content in the biodiesels was less compared to diesel. So it leads to an increase in fuel consumption.

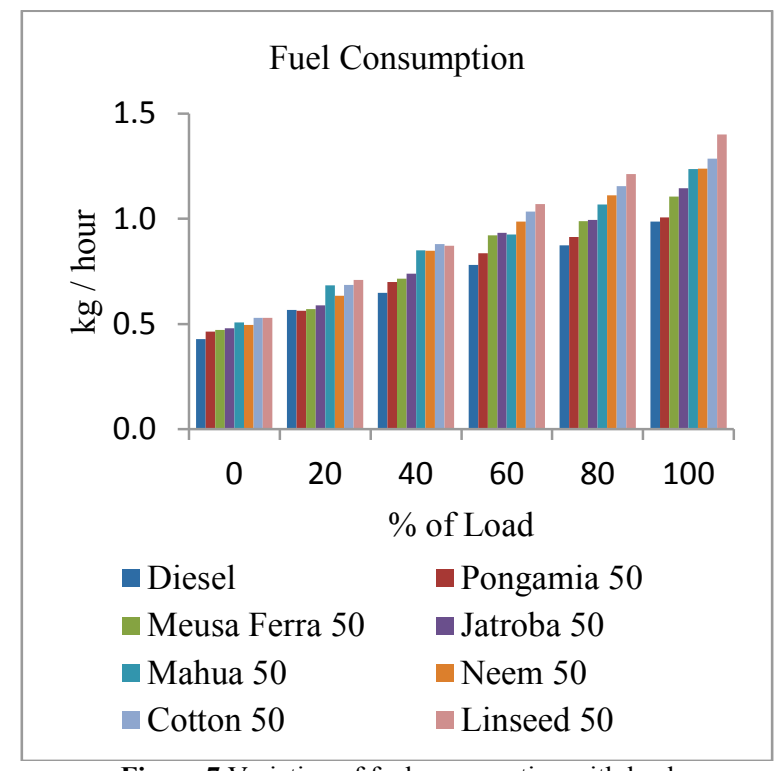

Figure 7 Variation of fuel consumption with load

\subsection{Carbon monoxide}

Fig. 8 shows the results of $\mathrm{CO}$ emission of different fuels for various load conditions. It is noticed that the value of $\mathrm{CO}$ decreases with increase in load irrespective of fuels. The emission of carbon monoxide depends upon the oxygen content of the fuel. In biodiesel oxygen content is more when compared with diesel. So the biodiesels are involved in complete combustion process and the carbon monoxide emission gets decreased. From the results, nearly $15 \%$ of CO emission was reduced using biodiesels.

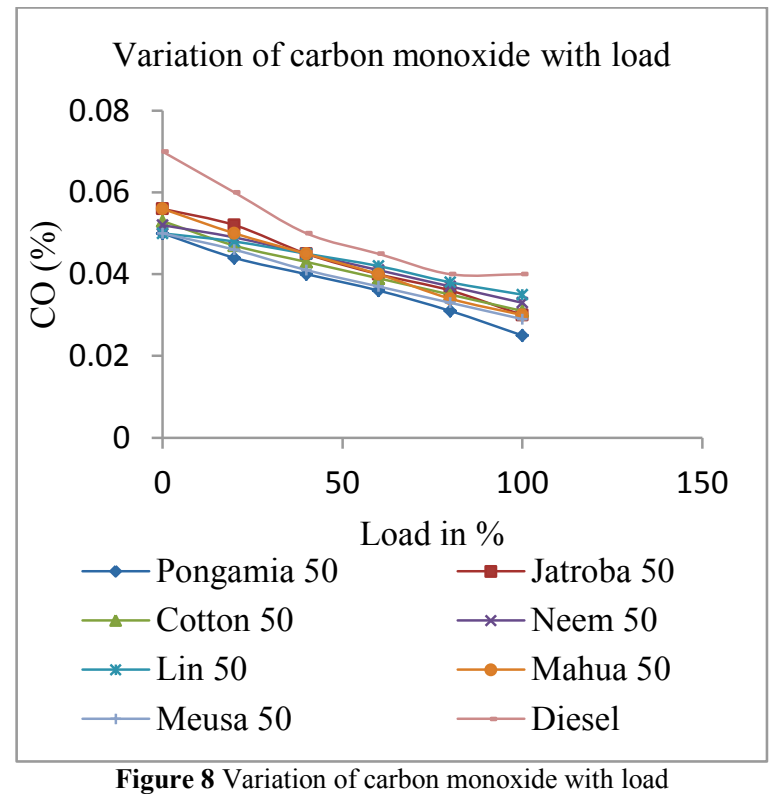

\subsection{Hydrocarbon}

Comparison of hydrocarbon values is shown in Fig. 9. Due to improper combustion the Hydro Carbon (HC) is released from the engine. But biodiesels have higher oxygen content, so complete combustion takes place. As a result the emission of hydrocarbon is reduced by $7 \%$. All biodiesels have less $\mathrm{HC}$ emission than that of petro-diesel.

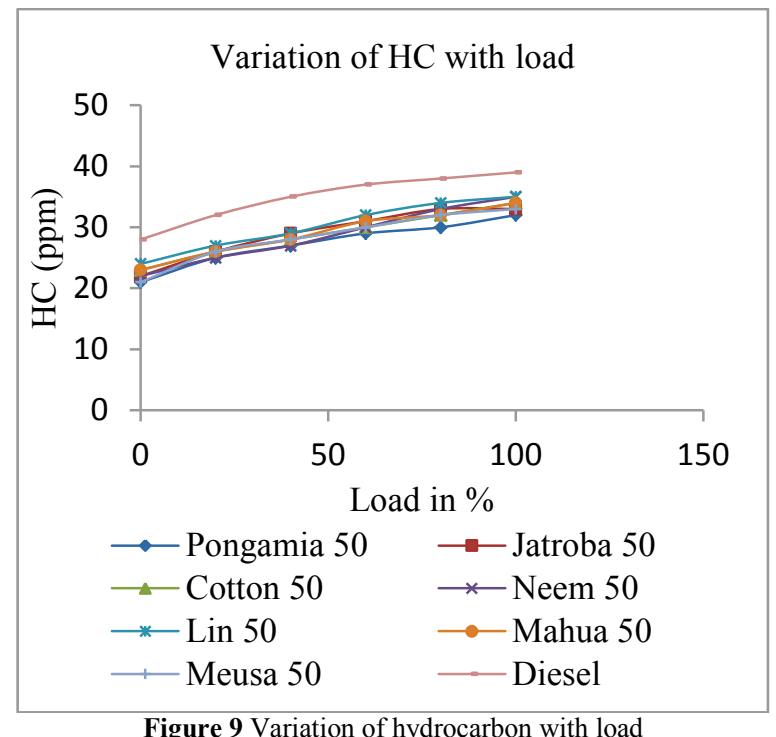

\subsection{Carbon dioxide}

The emission of carbon dioxide is shown in Fig. 10. It arises due to the complete combustion of the fuel. Carbon dioxide emission from diesel fuel is less because of the incomplete combustion. The biodiesel produces more 
carbon dioxide but plants are readily absorbing carbon dioxide and hence these levels are kept in balance.

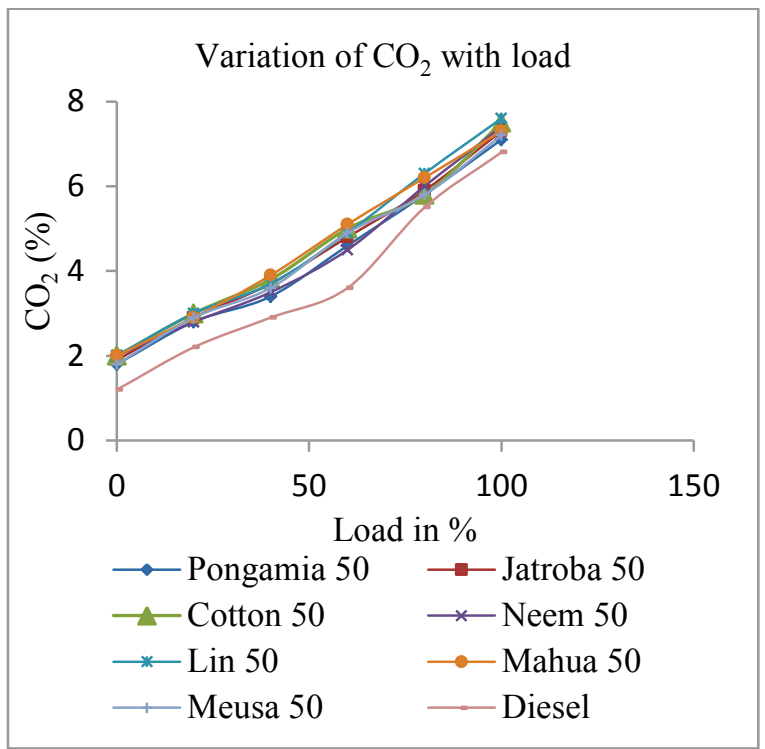

Figure 10 Variation of carbon dioxide with load

\subsection{Nitrogen oxide}

Fig. 11 shows the variation of nitrogen oxide (NOx) emissions. It depends on the combustion chamber temperature. A short ignition delay and atmospheric temperature reduce the cylinder temperature which suppresses the $\mathrm{NO}_{x}$ formation. Due to short ignition delay in biodiesel, the $\mathrm{NO}_{x}$ emissions are reduced by $6 \%$. At higher load conditions $\mathrm{NO}_{x}$ may increase due to increase in cylinder temperature.

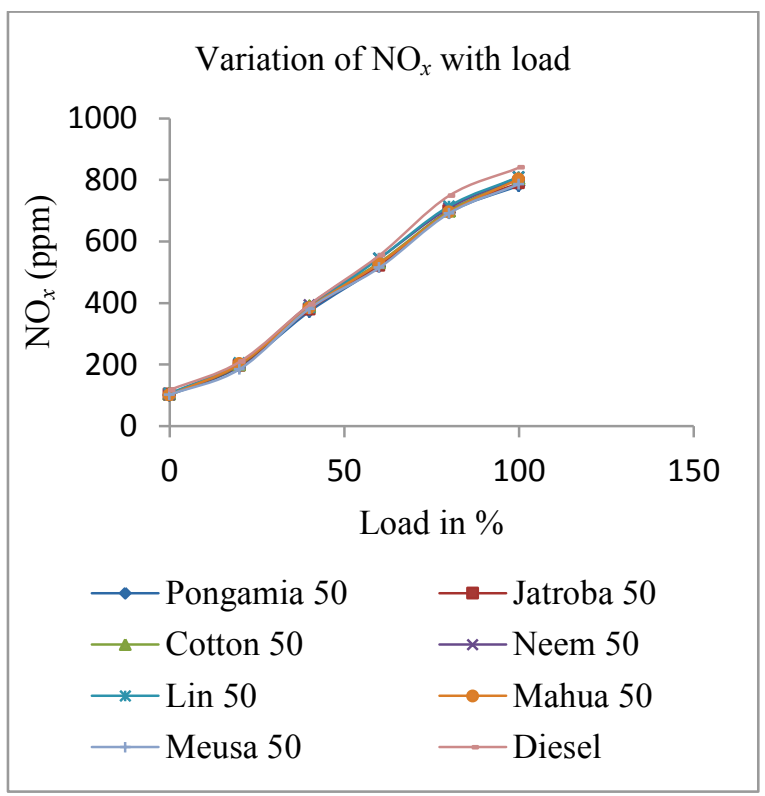

Figure 11 Variation of nitrogen oxide with load

\subsection{Smoke}

Smoke emissions of biodiesels are shown in Fig. 12. For all fuels smoke increases with increase in load. The smoke density increases due to high viscosity, it results in larger fuel droplet size and decrease in fuel air mixing rate. These are the factors involved in increasing the smoke density of biodiesel. But the high viscosity increases the lubricity.

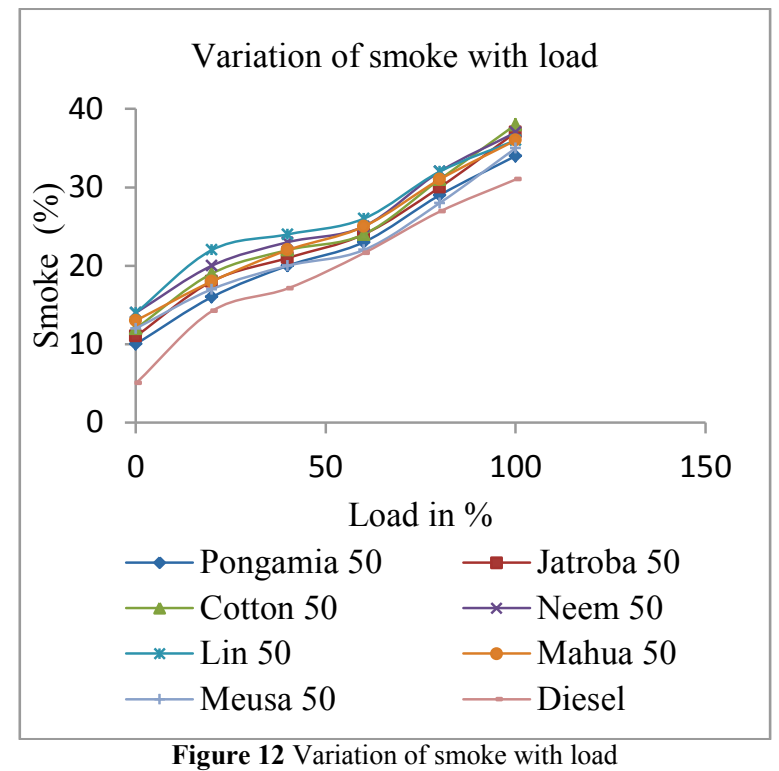

\section{Conclusion}

The present study encompasses the utilization of renewable energy sources for energy access in rural areas. As the main finding of this study, the rural electrification using diesel power generator fuelled with biodiesel derived from non-edible oils. Diesel generators are used to deliver essential stand-by power during peak load conditions. Bio Diesel is an ideal choice to meet the energy requirement. From the results, the methyl esters of non-edible oils can be used as an alternative for diesel power generators without any modification. In addition the emissions are considerably reduced. Among the selected resources pongamia has the best performance in all aspects. In resistive load some fuels deviate from standard voltage regulation characteristics, better voltage regulation was observed for non-linear load and the remaining parameters such as fuel consumption, frequency and emission parameters are similar in resistive load. And the problem observed during the test was that with increase in load, frequency and voltage get decreased. This may be overcome by using a closed loop operation or implementing the power electronic converters. By improving the hydrogen content in the biodiesel, the efficiency may improve which will avoid engine derating and additional fuel consumption. The increased lubricity of biodiesel has the ability to reduce the wear and tear on the engine and ultimately lead to longer engine life. This work may further be extended by analyzing the performance of closed loop operation.

\section{References}

[1] Rahman, T. K. A.; Rahim, S. R. A.; Musirin, I. Optimal allocation and sizing of embedded generators. // In: Proceedings of National Power and Energy Conference, 2930 Nov 2004. pp. 288-294. https://doi.org/10.1109/PECON.2004.1461660

[2] Georgilakis, S.; Katsigiannis, A. Reliability and economic evaluation of small autonomous power systems containing 
only renewable energy sources. // Renew Energy. 34, 1(2004), pp. 65-70.

https://doi.org/10.1016/j.renene.2008.03.004

[3] Cherni, J.; Dyner, I.; Henao, F.; Jaramillo, P.; Smith, R.; Olalde, R. Energy supply for sustainable rural livelihoods: A multicriteria decision-support system. // Energy Policy. 35, 3(2007), pp. 1884-1895 https://doi.org/10.1016/j.enpol.2006.03.026

[4] Martin, N. Plant Oils as Fuels: Present State of Science and Future Developments. // Proc. symposium held in Potsdam, Germany, 1997, pp. 276.

[5] Demirbas, A. Alternatives to Petroleum Diesel Fuel. // Energy Sources, Part B: Economics, Planning, and Policy. 2, 4(2007), pp. 343-351 https://doi.org/10.1080/15567240600629518

[6] Ashwani Kumar, et al. Potential non-edible oil resources as biodiesel feedstock: An Indian perspective. // Renewable and Sustainable Energy Reviews. 15, 4(2011), pp. 17911800. https://doi.org/10.1016/j.rser.2010.11.020

[7] Demirbas, A. Potential Resources of Non-edible Oils for Biodiesel. // Energy Sources, Part B: Economics, Planning, and Policy. 4, 3(2009), pp. 310-314. https://doi.org/10.1080/15567240701621166

[8] Atabani, A. E. et al. A comprehensive review on biodiesel as an alternative energy resource and its characteristics. // Renewable and Sustainable Energy Reviews. 16, 2012, pp. 2070-2093. https://doi.org/10.1016/j.rser.2012.01.003

[9] Eevera, T. Characterization of Groundnut Oil-based Biodiesel to Assess the Feasibility for Power Generation. // Energy Sources, Part A: Recovery, Utilization, and Environmental Effects. 33, 14(2011), pp. 1354-1364. https://doi.org/10.1080/15567030903330884

[10] Cetinkaya, M. et al. A New Application Area for Used Cooking Oil Originated Biodiesel Generators. // Energy and fuels. 19, 2(2005), pp. 645-652. https://doi.org/10.1021/ef049890k

[11] Ioannis Sadiktsis, et al. Particulate associated polycyclic aromatic hydrocarbon exhaust emissions from a portable power generator fuelled with three different fuels - A comparison between petroleum diesel and two biodiesels. // Fuel. 115, (2014), pp. 573-580. https://doi.org/10.1016/j.fuel.2013.07.062

[12] Eevera, T. et al. Cotton Seed Oil: A Feasible Oil Source for Biodiesel Production. // Energy Sources, Part A: Recovery, Utilization, and Environmental Effects. 35, 12(2013), pp. 1118-1128. https://doi.org/10.1080/15567036.2010.514648

[13] Eevera, T. et al. The Characterization of Palm and Rice Bran Oil Biodiesel to Assess the Feasibility for Power generation. // Energy Sources, Part A: Recovery, Utilization, and Environmental Effects. 36, 2(2014), pp. 150-157. https://doi.org/10.1080/15567036.2010.533332

[14] Kalbande, S. R. et al. Biodiesel production from NonEdible oil of Jatropha and Karanj for Utilization in Electrical Generator. // Bioenergy research. 1(2008), pp. 170-178. https://doi.org/10.1007/s12155-008-9016-8

[15] Valente, O. S. et al. Fuel consumption and emission from a diesel power generator fuelled with castor oil and soybean biodiesel. // Fuel. 89, 12(2010), pp. 3637-3642. https://doi.org/10.1016/j.fuel.2010.07.041

[16] Lin, Y. C.; Lee, W. J.; Hou, H. C. PAH emissions and energy efficiency of palm biodiesel blends fuelled on diesel generator. // Atmospheric Environment. 40, 21(2006), pp. 3930-3940. https://doi.org/10.1016/j.atmosenv.2006.02.026

[17] Pereira Roberto, G. et al. Exhaust emissions and electric energy generation in a stationary engine using blends of diesel and soybean biodiesel. // Renewable Energy. 32, 14(2007), pp. 2453-2460.

https://doi.org/10.1016/j.renene.2006.05.007
[18] Kennedy, J. M.; Best, R. J.; Morrow, D. J.; Fox, B. Performance Evaluation of Biodiesel Fuelled Electrical Generation. Power and Energy Society General Meeting, 2010, pp. 1-7. https://doi.org/10.1109/PES.2010.5589921

[19] Achten, W. M. J.; Verchot, L.; Franken, Y. J. Jatropha biodiesel production and use. // Biomass Bioenergy. 12, (2008), pp. 1063-1084. https://doi.org/10.1016/j.biombioe.2008.03.003

[20] Shahid, E. M. et al. Production of biodiesel: a technical review. // Renewable and Sustainable Energy Reviews, 15, 9(2011), pp. 4732-4745.

https://doi.org/10.1016/j.rser.2011.07.079

\section{Authors' addresses}

S. Durairaj, Assistant Professor

K. S. Rangasamy College of Technology Tiruchengode 637215, Tamilnadu, India durairajeeebe@gmail.com

\section{K. Sathiyasekar, Professor}

S. A. Engineering College, Chennai 600 077, Tamilnadu, India

ksathiyasekar@gmail.com

\section{Ilangkumaran, Professor}

K. S. Rangasamy College of Technology Tiruchengode 637215, Tamilnadu, India maniilankumaran@gmail.com 